\title{
Työmäärämuutokset maitotilalla ulkoistettaessa hiehonkasvatus
}

\author{
Markku Lätti ${ }^{1}$, Veli-Matti Tuure ${ }^{1}$, Kati Partanen ${ }^{2}$, Tapani Kivinen ${ }^{3}$ \\ ${ }^{1}$ TTS,PL 5, 05201 Rajamäki, markku.latti@tts.fi,veli-matti.tuure@tts.fi \\ ${ }^{2}$ Savonia-ammattikorkeakoulu,PL 72, 74101 Iisalmi, kati.partanen@savonia.fi \\ ${ }^{3}$ Maa-ja elintarviketalouden tutkimuskeskus, Vakolantie 55, 03400 Vihti, tapani.kivinen@mtt.fi
}

\section{Tiivistelmä}

Suunnitellessaan tilansa maidontuotannon laajentamista tuottajan on punnittava, millaiset edellytykset tilalla on tähän toisaalta olemassa olevaa tuotantorakennusta hyödyntämällä tai vaihtoehtoisesti uudisrakentamalla. Tilan laajentaessa toimintaansa työvoiman riittävyys voi tulla rajoittavaksi tekijäksi, sillä työmäärä yleensä kasvaa, vaikka työtä saadaankin tehostettua eli työmäärä tuotantoyksikköä kohti pienenee.

Tilan tuotannon siirtäminen suurempaan kokoluokkaan edellyttää aina hyvin suunniteltua töiden järjestämistä ja hyvää logistiikan suunnittelua. Keinoina voi olla muuan muassa tehokkaamman teknologian hankinta, prosessien tehostaminen, ulkopuolisen työvoiman palkkaaminen tai joidenkin töiden ulkoistaminen. Yksi keino tehostaa toimintaa ja organisoida maidontuotantotilojen työtä on ulkoistaa hiehonkasvatus siihen erikoistuneelle hiehonkasvatustilalle. Lypsykarjatilan ulkoistaessa hiehonkasvatuksen valtaosa nuorkarjatöistä jää pois ja vastaava työaika vapautuu varsinaiseen tuotantoon - maidontuottamiseen.

Hiehohotelli - hiehonkasvatuksen ulkoistaminen -tutkimushankkeen yksi tavoitteista oli selvittää hiehonkasvatuksen ulkoistamisen vaikutukset lypsykarjatilojen työnkäyttöön. Tutkimushankkeen tulokset osoittavat, että hiehonkasvatuksen ulkoistamisella hiehohotelleihin on yleensä mahdollista tehostaa lypsykarjatilojen työnkäyttöä. Tulokset ovat kuitenkin riippuvaisia käytetyistä työmenetelmistä ja mahdollisista muutoksista eläinmäärissä, ja siksi tarkastelu on hiehonkasvatuksen ulkoistamista suunniteltaessa tehtävä aina tapauskohtaisesti.

Ulkoistettaessa hiehonkasvatus olemassa olevasta tuotantorakennuksesta työmäärä ei välttämättä vähene. Se voi jopa kasvaakin, jos hiehoilta vapautuville paikoille remontoidaan tilat lypsylehmille. Työmäärän kasvu voi tällaisissa tapauksissa olla huomattavaakin, ellei samalla ulkoisteta ainakin joitain peltotöitä ja/tai investoida työtä helpottavaan teknologiaan etenkin lypsyn osalta.

Hiehonkasvatus ja samalla mahdollisesti pelto- ja muita töitä ulkoistamalla jopa kahden robotin kokoluokan tuotanto pystytään vielä hoitamaan yrittäjäpariskunnan tai kahden yrittäjän työpanoksella. Lisätyövoimaa tarvitaan kuitenkin sesonkiaikoina ja eläinten siirroissa. Pelkkä säästö työmäärässä ei välttämättä yksin kannusta hiehonkasvatuksen ulkoistamiseen. Jos ulkoistamisen tavoitteena on vain vähentää työmäärää olemassa olevasta tuotannosta, kannattavuudesta joudutaan yleensä tinkimään. Tämä on hyvä pitää mielessä hiehonkasvatuksen ulkoistamista suunniteltaessa.

Asiasanat: Työmäärä, hiehonkasvatus, ulkoistaminen, maidontuotanto 


\section{Johdanto}

Maidontuotantoa laajennettaessa työmäärä yleensä lisääntyy voimakkaasti. Haasteena on työmäärän pitäminen kohtuullisena käytettäviin työvoimaresursseihin nähden. Tyypillisesti lypsykarjatilalla lehmät, hiehot ja muu nuorkarja ovat samassa tuotantorakennuksessa. Hiehoille on oltava omat makuuparret, erillinen ruokinta ja niiden hoito vaatii työtä. Hiehojen kasvatuksen työmäärää ei lypsykarjatiloilla tyypillisesti oteta erikseen huomioon, vaan hiehojen kasvatuksen oletetaan tapahtuvan muun toiminnan sivussa. Käytännössä hiehojen kasvatus kuitenkin sekä vaatii työtä että aiheuttaa kustannuksia.

Kaiken tuotantotoiminnan suunnittelun yksi tärkeä lähtökohta on toimintaan käytettävissä oleva työvoima. Tilan laajentaessa toimintaansa työvoiman riittävyys voi tulla rajoittavaksi tekijäksi, sillä työmäärä yleensä kasvaa, vaikka työtä saadaankin tehostettua eli työmäärä tuotantoyksikköä kohti pienenee. Tilalle voidaan tietysti palkata ulkopuolista työvoimaa, jos tällaista on tarjolla ja taloudelliset edellytykset palkkaamiseen ovat kunnossa. Työmäärän arviointi on siten toiminnan laajuuden ja talouden suunnittelun keskeinen tarkastelualue. Etenkin voimakkaasti laajentavien maitotilojen toiminta vaatii aina hyvin suunniteltua töiden järjestämistä ja hyvää logistiikan suunnittelua.

Yksi mahdollinen keino hallita maidontuotantotilojen työmäärää on ulkoistaa hiehonkasvatus siihen erikoistuneelle hiehonkasvatustilalle. Vuoden 2009 ja 2010 Tonkka tietojen mukaan (6600 tilan tiedot) 95,2 \% tiloista kasvattaa kaikki hiehot itse (>60 lehmän karjoissa 89,3\%), 0,7\% on ulkoistanut hiehon kasvatuksen kokonaan (>60 lehmän karjoissa 2,3\%) ja 1,5\% osittain (>60 lehmän karjoissa $3,9 \%$ ) ja 2,4 \% ostaa osan hiehoista (>60 lehmän karjoissa 4,4 \%). (ProTuotos tulokset 2009 ja 2010, ProAgria Keskusten Liitto). Hiehojen kasvatuksen ulkoistaminen ei siis ole vielä kovin yleistä, mutta on yleistymässä etenkin suuremmilla lypsykarjatiloilla.

Lypsykarjatilan ulkoistaessa hiehonkasvatuksen valtaosa nuorkarjatöistä jää pois ja vastaava työaika vapautuu varsinaiseen tuotantoon - maidontuottamiseen. Yleistä on myös, että tuotantorakennukseen kohdistuvia hiehonkasvatuksen toiminnallisia vaatimuksia ja kannattavuutta ei ole juuri otettu huomioon. Hiehonkasvatukseen erikoistuneella tilalla kaikki toiminnot ja työ on taas suunniteltu hiehojen kasvatuksen näkökulmasta.

Tutkimuksen tavoitteena oli selvittää hiehonkasvatuksen ulkoistamisen mahdollisuudet ja rajoitteet - niin maidontuottajan kuin hiehonkasvattajankin näkökulmista. Yksi päänäkökulmista oli ulkoistamisen vaikutukset työnkäyttöön: kuinka työmäärä muuttuu kasvatettaessa hiehot lypsykarjatilalla/hiehokasvattamossa sekä kuinka paljon työaikaa hiehojen siirrot tilojen sisällä ja välillä vaativat. Mielenkiintoinen tarkastelukohde oli myös se, kuinka paljon lehmäpaikkoja voidaan lisätä nuorkarjalta ulkoistettaessa vapautuvaan tilaan ja kuinka tämä muutos vaikuttaa maitotilan työmäärään. Tässä esityksessä on keskitytty tarkastelemaan tilannetta maidontuotantotilan kannalta. Tutkimus toteutettiin vuosina 2009-2011 yhteistyössä Savonia ammattikorkeakoulun, TTS - Työtehoseuran, Maa- ja elintarviketalouden tutkimuskeskuksen (MTT), Elintarviketurvallisuusviraston (EVIRA) ja Eläintautien torjuntayhdistyksen (ETT) kanssa.

\section{Aineisto ja menetelmät}

Hiehonkasvatuksen ulkoistamisen vaikutuksia lypsykarjatilojen työnkäyttöön tutkittiin muodostamalla tilamalleja tilakokoluokkiin, jotka ovat potentiaalisia ulkoistamaan hiehonkasvatuksen. Lypsykarjatilamalleja muodostettiin yhteensä viisi:

- Tilamalli 1: 22 lypsylehmän parsinavettatila ulkoistaa osan hiehonkasvatuksesta ja lisää lypsylehmäpaikkoja $8 \mathrm{kpl}$

- Tilamalli 2: 22 lypsylehmän parsinavettatila ulkoistaa hiehonkasvatuksen kokonaan ja lisää lypsylehmäpaikkoja $13 \mathrm{kpl}$

- Tilamalli 3: yhden lypsyrobotin pihatto ulkoistaa hiehonkasvatuksen kokonaan, lisää lehmämäärää $(70 \rightarrow 125)$ ja hankkii toisen robotin

- Tilamalli 4: rakennetaan kokonaan uusi pihatto kahdelle robotille, jossa hiehonkasvatus ulkoistettu (153 lehmää)

- Tilamalli 5: rakennetaan kokonaan uusi pihatto kahdelle robotille, jossa kasvatetaan myös hiehot (153 lehmää)

Kolme ensimmäistä mallia käsittelevät tuotannon laajentamista olemassa olevissa tuotantorakennuksissa ja kaksi viimeistä tilannetta, jossa mietitään kokonaan uuden tuotantorakennuksen raken- 
tamista hiehopaikoilla tai ilman. Lisäksi tutkimuksessa muodostettiin tilamalleja hiehonkasvatukseen (hiehokasvattamomalleja), joita ei kuitenkaan käsitellä tässä yhteydessä

Tilamalleihin laaditut kotieläintöiden työmäärälaskennat tehtiin rääälöityinä laskelmina käyttäen lähtötietoina pääosin maatalouden standardiaikajärjestelmään kirjattuja ja työntutkimuksiin perustuvia menetelmäkohtaisia työaikatietoja. Laskentavälineinä käytettiin TTS Manager -ohjelmaa sekä Excel-taulukkolaskentaohjelmaa. Osa nuorten eläinten hoidon työaikatiedoista on peräisin saksalaisesta KTBL:n standardiaikatietokannasta (KTBL 2008). Standardiaikatietoja täydennettiin Hiehohotelliprojektin aikana toteutetuilla aikatutkimuksilla maatiloilla sekä harvoin toistuvien töiden osalta maatalousyrittäjiltä haastattelemalla saaduilla työaikatiedoilla. Tutkimuksessa vierailtiin yhteensä kahdeksalla hiehonkasvatuksen ulkoistaneella lypsykarjatilalla (28-165 lypsylehmää/tila) ja kahdeksalla hiehonkasvatukseen erikoistuneella tilalla (26-400 hiehoa/tila), joilla kartoitettiin menetelmätietoja, seurattiin eläinten siirtoja, tehtiin työaikatutkimuksia ja haastateltiin tilojen yrittäjiä.

Maatiloilla tehdyt täydentävät työntutkimukset kohdistuivat erityisesti lypsyrobottitilojen eläinten päivittäisiin hoitotöihin, seosrehuruokintaan, nuorkarjan hoitotöihin sekä nautojen siirtotöihin. Työntutkimukset toteutettiin koko työpäivän mittaisina tutkimusjaksoina maatilan normaalin työpäivän aikana pääosin niin sanotulla jatkuvan ajan menetelmällä.

Muiden kuin nuorkarjatöiden, robottilypsyn ja seosrehuruokinnan osalta (lypsylehmien vaatimat muut työt, peltotyöt sekä maatilan suunnittelu- ja johtamistyöt) laskelmat tehtiin TTS-Manager ohjelmalla (maatilan töiden kokonaistyömäärälaskentaohjelma), joka niin ikään käyttää maataloustöiden standardiaikajärjestelmää (työntutkimuksiin perustuvaa työmenetelmäkohtaista työaikatietokantaa).

Työmäärälaskennan räätälöinnin tarve aiheutui siitä, että eläinten hoitotyö jakautuu eri toimijoille - maidontuotantotilalle ja hiehohotellitilalle - eläinten ikäkausien mukaan eikä kyseisenlaiseen tarkasteluun, jossa toimijoiden osuudet voidaan erottaa toisistaan, ollut käytettävissä valmista laskentapohjaa. Niinpä nuorkarjan hoitotöiden työmäärälaskelmat laadittiin ikäryhmäkohtaisesti. Tällöin voitiin ottaa huomioon mm. eri-ikäisten eläinten rehuntarve. Käsiteltävät rehumäärät saatiin tällöin laskettua tarkasti lisäämällä rehuntarpeeseen rehuhukka, joka jaettavasta rehusta riippuen on luokkaa 5-10 \% rehumäärästä. Käsiteltävä rehumäärä puolestaan vaikuttaa työaikaan, joka näin pystyttiin määrittämään kasvatusvaiheen eri tilanteissa. Tämä oli tarpeen, sillä hiehohotellikonseptissa eläinten alkukasvatus tapahtuu maidontuotantotilalla, nuorkarjan kasvatus tämän jälkeen hiehohotellitilalla ja kantavan hiehon kasvatus edelleen maidontuotantotilalla, ja näin eri tiloille kohdistuvat työmäärät saatiin selvitettyä.

Malleissa käytettiin kahta erilaista strategiaa eläinten siirtoiän suhteen. 30 lehmän parsinavettamallissa hiehot siirrettiin kasvattajalle maitotilan laidunkauden lopussa (pois lukien sisäruokintakaudella poikivat hiehot) ja taas takaisin maitotilalle laidunkauden alussa, jolloin maitotila pystyi hyödyntämään laidunalueita nuorkarjan kasvatuksessa. 35 lehmän mallissa ternivasikoita ja poikimista odottavia ( $2 \mathrm{kk}$ poikimiseen) hiehoja siirrettiin joka kuukausi, jolloin parsinavettaan vapautui enemmän parsipaikkoja lypsylehmille.

Pihattomalleissa vasikoita siirrettiin terneinä kasvattamoon joka kuukausi. Samoin hiehoja siirrettiin 2 kuukautta ennen poikimista takaisin lypsykarjatilalle joka kuukausi. Kaikissa malleissa sonnivasikat menivät välitykseen terneinä.

Työnkäyttö laskettiin vuositasolla töittäin ja lisäksi nuorkarjan hoitotöiden osalta ikäluokittain.

\section{Tulokset}

Hiehonkasvatuksen ulkoistamisen kannattavuus riippuu paljon siitä, mitä tulee nuorkarjan tilalle. Jos ulkoistamisen tavoitteena on pelkästään työmäärän vähentäminen eläinmäärää vähentämällä, tilan kannattavuus ei yleensä parane. Toisaalta työmäärä saattaa lypsylehmien määrää lisätessä kasvaa huomattavastikin, ellei vastaavasti investoida työtä helpottavaan teknologiaan.

\section{Hiehonkasvatuksen ulkoistus parsinavetasta}

Parsinavettamalleissa on ennen muutosta 22 lypsylehmää. Ensimmäisessä mallissa ulkoistetaan 11 hiehon kasvatus siten, että hiehot lähtevät vuosittain ryhmäkuljetuksena lokakuussa kasvattamoon ja palaavat maitotilalle takaisin ryhmäkuljetuksena toukokuun lopulla suoraan laitumelle. Hiehot ovat kasvattamossa yhtäjaksoisesti noin 7 kk. Pienimmät kasvattamoon menevät hiehot ovat 3 kk ikäisiä. 
Hiehokasvatuksen ulkoistaminen mahdollistaa tilan lehmämäärän nousun kolmeenkymmeneen, jolloin tilalla tuotetun maidon määrä kasvaa. Usein nurmiala muodostuu rajoittavaksi tekijäksi tilakoon kasvussa. Kun hiehokasvatus ulkoistetaan ja lehmämäärä kasvaa, myös nurmialan tarve kasvaa. Koska hiehot palaavat kotitilalle laidunkaudeksi, myös laitumen tarve kasvaa varsin paljon. Esimerkkitilalla peltoalaa on nurmialan tarvetta enemmän, joten se ei muodostu rajoittavaksi tekijäksi. Parsinavettamalleissa kaikki peltotyöt tehdään tilan omalla työvoimalla.

Laajennettaessa parsinavetassa 22 lehmästä 30 lehmään hiehonkasvatus osittain ulkoistaen (kuljetukset laidunkauden alussa ja lopussa) vuotuinen työmäärä on 4072 tuntia eli kasvaa noin 140 tuntia, johtuen pääasiassa lehmämäärän kasvusta (kuva 1). Lehmää kohti käytettävä työmäärä kuitenkin pienenee osin siksi, että navettaan hankitaan kaksi lypsy-yksikköä lisää. Ilman tätä investointia työmäärä kasvaisi noin 500 tuntia vuodessa.

Jos kuljetuksia lypsykarjatilan ja kasvattamon välillä on joka kuukausi ja vasikat lähtevät jo ternijuottovaiheessa noin kahden viikon ikäisinä kasvattamoon, lypsylehmien määrää on mahdollista lisätä lähtötilanteesta (22 lehmää) 35 lehmään (tilamalli 2). Laajennettaessa 22 lehmästä 35 lehmään hiehonkasvatus kokonaan ulkoistaen työmäärä on 4257 tuntia eli kasvaa noin 330 tuntia johtuen pääasiassa lehmämäärän kasvusta (kuva 1).

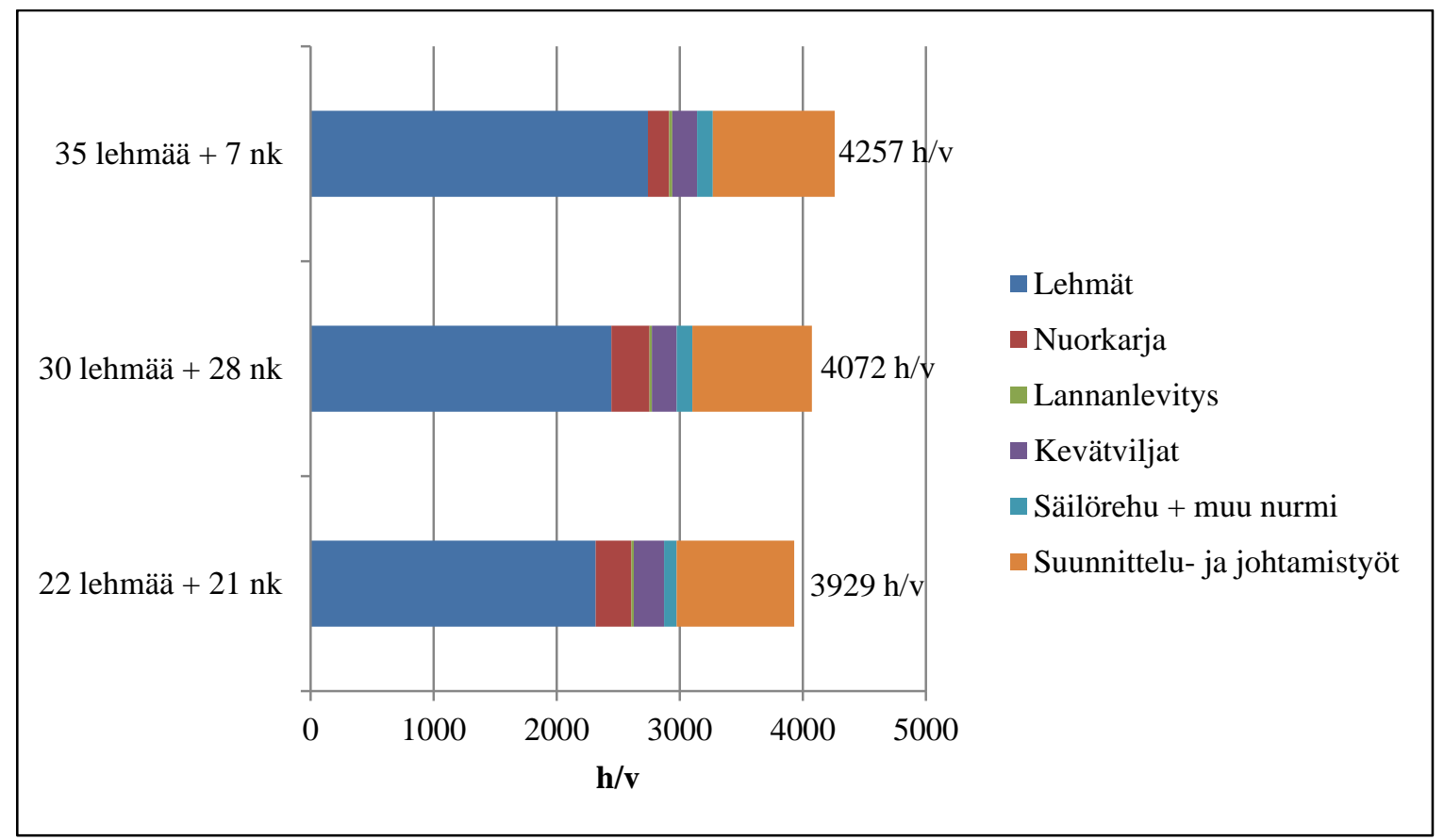

Kuva 1. Työmäärä h/v 22 lypsylehmän tilalla, jossa maitotila kasvattaa uudistukseen tarvittavan nuorkarjan (nk) itse, 30 lehmään laajentaneella hiehonkasvatuksen osittain ulkoistaneella tilalla sekä 35 lehmään laajentaneella tilalla, jossa hiehonkasvatus on ulkoistettu kokonaan.

Vasikoiden siirtoiällä kasvattamoon (joko välikasvattamo tai varsinainen hiehokasvattamo) on merkitystä etenkin suurien lypsykarjatilojen työmäärään ulkoistustilanteessa. Vasikoiden alkukasvatus eli juotto vaatii suhteellisen paljon työtä (kuva 2), joten mitä aikaisemmin vasikat lähtevät kasvattajalle, sitä enemmän lypsykarjatilalla on aikaa varsinaiseen maidontuotantoon. 


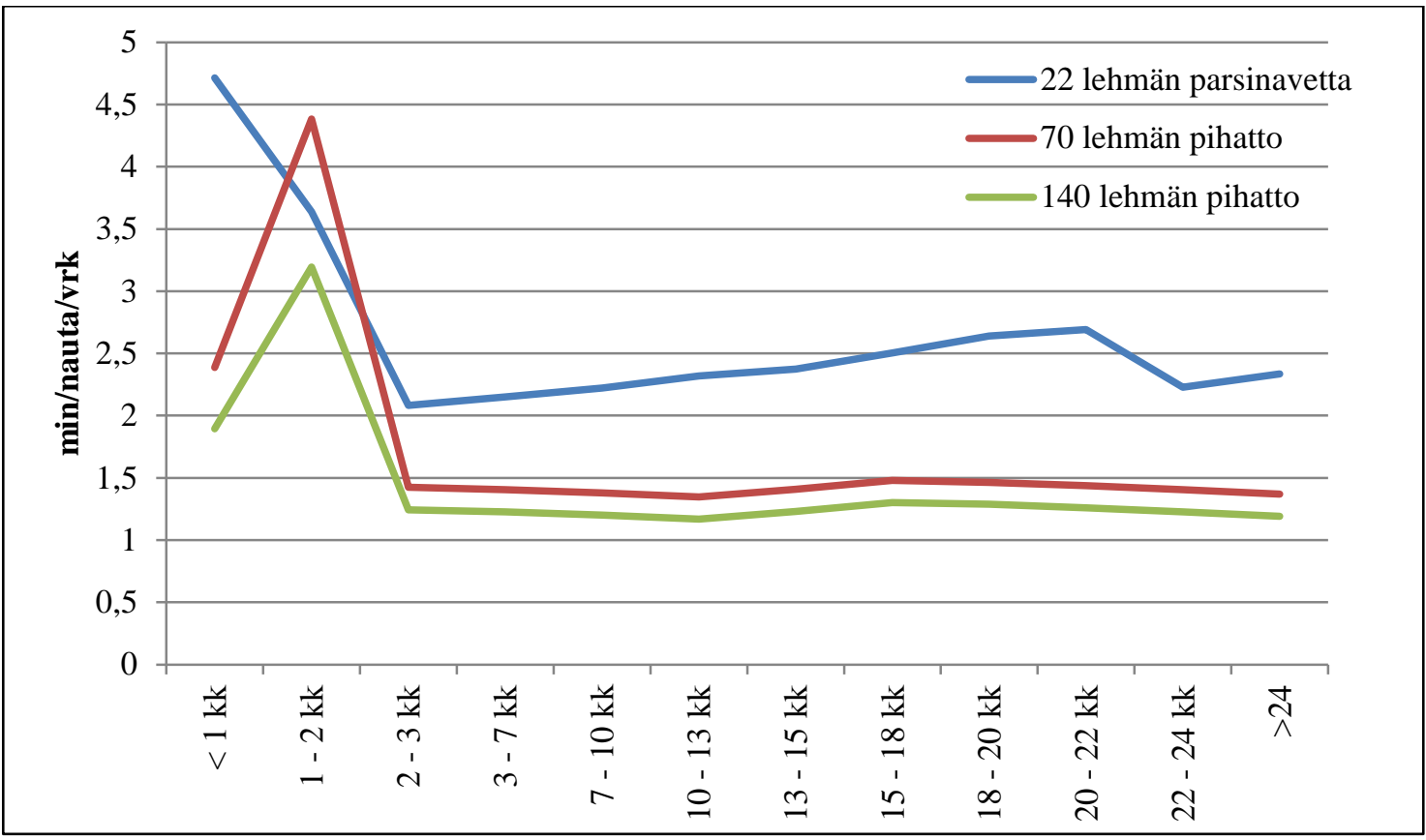

Kuva 2. Keskimääräinen työmäärä (min/eläin/vrk) naudan ikäluokittain erikokoisissa lypsykarjoissa.

\section{Yhdestä robotista kahteen hiehot ulkoistamalla}

Lähtötilanteessa tilan työmäärä on 4264 tuntia, johon sisältyy lehmien $(70 \mathrm{kpl})$ ja nuorkarjan $(68 \mathrm{kpl})$ hoitotyöt, peltoviljelyn kevättyöt, ruiskutukset, sadonkorjuutyöt, lannanlevitystyöt ja suunnittelu- ja johtamistyöt. Kun hiehojen kasvatus ulkoistetaan kahden viikon iästä lähtien niin, että hiehot palaavat tilalle kaksi kuukautta ennen poikimista ja lypsylehmien määrää lisätään rakennuksen sallimissa rajoissa 125 lehmään, navetassa tehtävä vuotuinen työmäärä lisääntyy 735 tuntia. Mallin kokonaistyömäärän kasvu olisi vieläkin suurempi, mikäli peltotöitä ei ulkoisteta. Mallissa tila keskittyy peltoviljelyssä säilörehun tuottamiseen ja käytännössä ulkoistaa lähes kaikki peltotyöt. Tila levittää itse väkilannoitteet pintalevityksenä ja huolehtii kevätmuokkauksesta. Näin koko tilan työmäärä kasvaa 470 tuntia lehmämäärän kasvaessa.

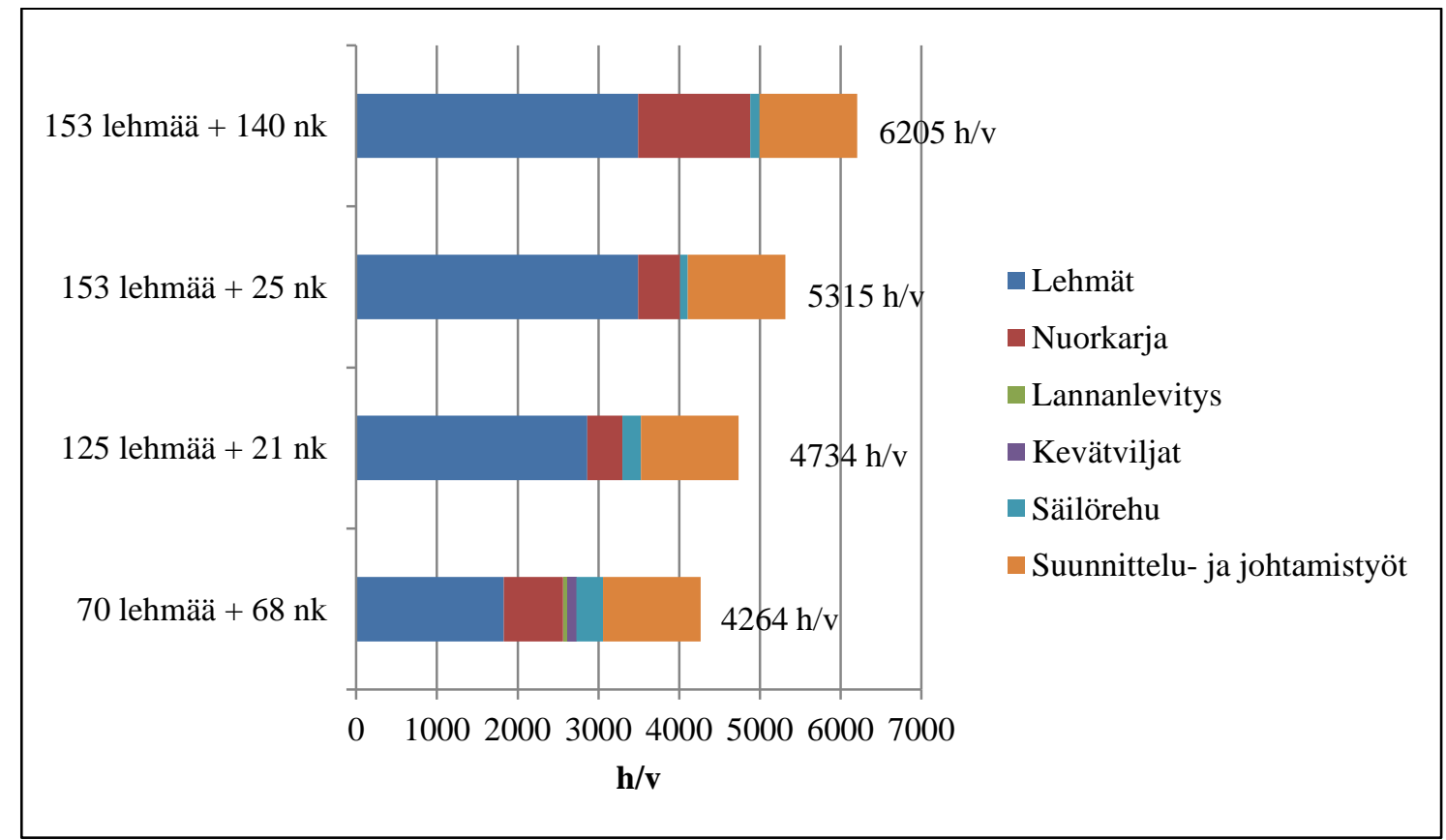

Kuva 3. Työmäärä yhden robotin pihattonavetassa, jossa uudistukseen tarvittava nuorkarja (nk) kasvatetaan itse, työmäärä edellisessä pihatossa hiehonkasvatuksen ulkoistuksen ja toisen robotin lisäyksen jälkeen ja työmäärät uudessa kahden robotin pihatossa hiehonkasvatus ulkoistettuna ja hiehot itse kasvattaen. 
Toteutetun muutoksen jälkeen työmäärä kasvaa 4734 tuntiin. Suurin lisäys tulee lypsylehmien karjanhoitotöihin, joiden määrä kasvaa noin 1826 tunnista 2861 tuntiin. Samaan aikaan nuorkarjan hoitotöiden tuntimäärä vähenee 733 tunnista 434 tuntiin. Lannanlevitys ulkoistetaan urakoijalle, joten sen työmäärä jää muutosvaiheessa pois. Muutoksen jälkeen kaikki vilja ostetaan, joten myös viljan vaatimat kevättyöt, ruiskutukset ja korjuutyö jäävät kokonaan pois. Säilörehutöistä uudistuksen perusmuokkaus, niitto, karhotus ja korjuu (mallissa pyöröpaalaus) teetetään urakoijalla, joten nekin vähentävät tilan kokonaistyömäärää pitäen sen kohtuullisen lähellä lähtötilannetta. Myös investoiminen suurempaan apevaunuun ( $15 \mathrm{~m}^{3}$ vaunusta $24 \mathrm{~m}^{3}$ vaunuun) tehostaa aperuokintaa ja pitää osaltaan työmäärää kurissa. Muutoksen jälkeen tilalla on edelleen mahdollisuus jatkaa kahden hengen työpanoksella tilapäistyövoimaa lisäksi hyödyntäen.

\section{Uusi pihatto nuorkarjalla vai ilman?}

Jos 153 lehmää (132 lypsyssä, 21 umpilehmää) ja uudistukseen tarvittava nuorkarja (keskimäärin 140 eläintä) hoidetaan kahden robotin yksikössä itse, kokonaistyömäärä on 6205 tuntia vuodessa (kuva 3). Isäntäpariskunnan lisäksi tarvitaan siis ainakin yksi työntekijä. Jos hiehokasvatus ulkoistetaan, kokonaistyömäärä putoaa 5315 tuntiin. Määrä ylittää vieläkin kahden henkilön vuosittaisen työpanoksen, joten kolmas henkilö tarvitaan myös ulkoistettaessa nuorkarjan kasvatus. Nuorkarjasta maitotilalle jäävät tällöin pikkuvasikat ja poikimista odottavat hiehot, keskimäärin 25 eläintä. Lehmävasikat lähetetään kasvattamoon terneinä ja tarvittava määrä hiehoja palaa maitotilalle $2 \mathrm{kk}$ ennen poikimista. Sonnivasikat lähtevät ternivasikoina välitykseen.

Nuorkarjan kasvatuksen ulkoistaminen vaikuttaa työmäärään pääasiassa vähentämällä nuorten eläinten hoitotyötä. Vaikutus on mallilaskelmissa 869 tuntia vuodessa. Nuorkarjan hoitotöiden määrä itse tehtynä on 1392 tuntia ja ulkoistettaessa hiehonkasvatus 523 tuntia vuodessa sisältäen myös umpilehmien ruokinnan ja puhtaanapidon. Vaikka nuorkarjan ulkoistaminen lisää eläinten siirtotyötä tilojen välillä, toisaalta tilan sisäisten eläinten siirtotöiden vaatima työmäärä vähenee. Esimerkkitilan työmäärälaskelmissa nämä lähes kompensoivat toisensa; ulkoistamisvaihtoehdossa eläinten siirtotöiden määrä on kuitenkin hieman suurempi kuin kasvatettaessa uudistuseläimet itse. Tilan eläinmäärän pienentäminen vähentää hieman tarvittavaa nurmialaa, joten myös peltotöiden määrä vähenee nuorkarjan kasvatuksen ulkoistamisen myötä. Tämä vaikutus on kuitenkin pieni, vain noin kolme työpäivää, sillä esimerkkitilalla molemmissa nuorkarjan kasvatusvaihtoehdoissa peltotöistä vain nurmien lannoitukset hoidetaan itse. Muut peltotyöt ulkoistetaan.

Nuorkarjan kasvatuksen ulkoistaminen vaikuttaa pienessä määrin myös lehmien hoitoon tarvittavaan aikaan. Lehmien hoitotöiden määrä itse asiassa kasvaa hieman, sillä umpilehmien aperuokinnan valmisteluissa ei saavuteta enää yhtä voimakasta synergiaetua kuin hoidettaessa nuorkarja itse. Vuositasolla vaikutus on kuitenkin vain parin työpäivänluokkaa. Yrittäjäpariskunnan oman työn määrä on molemmissa vaihtoehdoissa asetettu 4200 tuntiin vuodessa ja ylimenevälle osalle palkataan työvoimaa. Tässä tapauksessa nuorkarja saadaan hoidettua suunnitellussa osastossa varsin tehokkaasti. Usein tällaisen laajennuksen yhteydessä nuorkarjalle saneerataan vanha navetta, jossa työmäärä on suurempi kuin tässä esimerkissä.

\section{Tulosten tarkastelu}

Tilamallien tulokset osoittavat, että hiehonkasvatuksen ulkoistamisella hiehohotelleihin on mahdollista tehostaa lypsykarjatilojen työnkäyttöä. Työnkäyttötulokset ovat kuitenkin riippuvaisia käytetyistä työmenetelmistä ja mahdollisista muutoksista eläinmäärissä, ja siksi tarkastelu on hiehonkasvatuksen ulkoistamista suunniteltaessa tehtävä aina tapauskohtaisesti.

Malleista käy ilmi, että ulkoistettaessa hiehonkasvatus olemassa olevasta tuotantorakennuksesta, työmäärä ei välttämättä vähene, se voi jopa kasvaakin, jos hiehoilta vapautuville paikoille remontoidaan tilat lypsylehmille. Työmäärän kasvu voi tällaisissa tapauksissa olla huomattavaakin, ellei samalla ulkoisteta ainakin joitain peltotöitä ja/tai investoida työtä helpottavaan teknologiaan, etenkin lypsyn osalta. Näin tilojen työmäärä kasvaa vain maltillisesti lehmämäärän kasvaessa. Tuotantomääriä saadaan näin kuitenkin lisättyä ja tätä kautta tehokkuutta sekä kannattavuutta yleensä parannettua. Pelkkä säästö työmäärässä ei välttämättä yksin kannusta ulkoistamiseen. Jos ulkoistamisen tavoitteena on vain vähentää työmäärää olemassa olevasta tuotannosta, joudutaan kannattavuudestakin yleensä tinkimään. 
Voimakkaasti laajennettaessa, mikä yleensä tarkoittaa kokonaan uuden tuotantorakennuksen rakentamista, joudutaan miettimään oman työpanoksen riittävyyttä. Hiehonkasvatus ja samalla mahdollisesti pelto- ja muita töitä ulkoistamalla jopa kahden robotin kokoluokan tuotanto pystytään vielä hoitamaan yrittäjäpariskunnan tai kahden yrittäjän työpanoksella. Lisätyövoimaa tarvitaan kuitenkin sesonkiaikoina ja eläinten siirroissa. Vaikka hiehonkasvatuksen ulkoistaminen lisää eläinten siirtotyötä tilojen välillä, toisaalta tilan sisäisten eläinten siirtotöiden vaatima työmäärä vähenee. Tapauskohtaisesti tällaisen tuotannon laajennuksen yhteydessä voi olla järkevää saneerata vanha navetta nuorkarjalle, jos se on vertailulaskelmissa taloudellisesti kannattavaa ja työmäärä ja työn kuormittavuus ovat järkevällä tasolla. Hiehojen kasvatuksen ulkoistamista onkin tarkasteltava aina tilakohtaisesti.

Työmäärää laskettaessa ja arvioitaessa täytyy aina muistaa, että käytännössä tilojen välillä on suuria eroja työnmenekeissä johtuen muun muassa erilaisesta tekniikasta, käytetyistä työmenetelmistä, olosuhteista sekä työntekijöiden tavoista tehdä työtä. Suurimmillaan tämä ero voi esimerkiksi karjanhoitotöiden osalta olla jopa 2-3 -kertainen. (Kivinen ym. 2007). Etenkin lypsyn, jonka osuus kaikista karjanhoitotöistä on keskimäärin 50-60\%, työnmenekeissä on suurta vaihtelua samankokoisilla tiloilla. Jos siis lypsyn eri työnvaiheiden (ml. pesutyöt ja lehmäliikenteen ohjaus) työnmenekki on suuri jo ennen hiehonkasvatuksen ulkoistamista ja lehmämäärän lisäämistä, niin ilman parannuksia niissä työmäärä voi kasvaa kestämättömästi. Tilalla, jolla lypsyprosessi on kunnossa, lehmämäärän lisäys ei aiheuta samanlaista tilannetta.

Eläinten siirtojen työnmenekissä esiintyy käytännössä suurta vaihtelua, ja malleissa onkin käytetty tilatutkimusten ja haastatteluiden kautta saatujen aikojen keskiarvoja. Joskus siirrot voivat onnistua nopeasti, ja toisinaan niihin taas saa kulumaan tunteja siirroissa esiintyvien häiriötekijöiden vuoksi. Häiriötekijöiden eliminoiminen ja eläinten luontaisen käyttäytymisen tunteminen ovatkin avainasioita onnistuneisiin siirtoihin (Lätti 2004).

\section{Johtopäätökset}

Hiehonkasvatus ulkoistamalla maitotilan on mahdollista vähentää lypsylehmää kohti kuluvaa työaikaa, kun kaikki toiminnot voidaan suunnitella lehmien ehdoilla. Tämä mahdollistaa entistä suurempien lypsykarjayksiköiden rakentamisen myös työvoimaresurssien puitteissa. Tilalla, jolla on vanha tuotantorakennus, hiehonkasvatuksen ulkoistaminen mahdollistaa tuotannon laajentamisen - lypsylehmämäärän lisäämisen - olemassa olevissa tuotantotiloissa kohtuullisin kustannuksin hiehoilta vapautuville paikoille ilman työpanoksen suurta muutosta.

Maidontuotannon tehokkuutta ja erikoistumista onkin yleensä mahdollista kasvattaa ulkoistamalla hiehonkasvatus. Tarkastelu on kuitenkin tehtävä aina tapauskohtaisesti, sillä tilojen välillä on suuria eroja työn tehokkuudessa johtuen muun muassa erilaisesta tekniikasta, käytetyistä työmenetelmistä, olosuhteista sekä työntekijöiden tavoista tehdä työtä.

Lisäksi tilakohtaiset rajoitteet, kuten pellon ja työvoiman saatavuus, on määriteltävä ja selvitettävä vaihtoehdot niiden pohjalta. Tilakohtaiset järjestelyt vaikuttavat aina ratkaisuun, ja ennen investointipäätöstä eri vaihtoehtoja on punnittava huolellisesti niin talouden, työnkäytön kuin yrittäjäperheen tarpeidenkin kannalta.

Hankkeen aikana tehtyjen selvitysten perusteella voi olettaa, että hiehonkasvatuksen ulkoistaminen on kannattavinta silloin, kun tuotetun maidon määrää saadaan lisättyä ulkoistamalla hiehonkasvatus. Pelkkä säästö investointikustannuksessa tai työmäärässä ei välttämättä kannusta ulkoistamiseen.

\section{Kirjallisuus}

Kivinen, T., Kaustell, K.O., Hakkarainen, K., Tuure, V-M., Karttunen, J. ja Hurme, T. 2007. Lypsykarjapihaton toiminnalliset mitoitusvaihtoehdot. Maa- ja elintarviketalouden tutkimuskeskus. Teknologia. MTT:n selvityksiä 137. 149 s. Saatavilla Internetistä: http://www.mtt.fi/mtts/pdf/mtts137.pdf

Lätti, M. (toim.) 2004. Eläinten siirrot tuotantotiloissa. Työtehoseuran raportteja ja oppaita 10: 1-80. Helsinki. KTBL Datensammlung 2008. Betriebsplanung Landwirtschaft 2008/09. Daten für die Betriebsplanung in der Landwirtschaft. 21. Auflage 2008. 